Agnieszka Franczyk-Cegła ๑ http://orcid.org/0000-0002-1231-925X

Zakład Narodowy im. Ossolińskich, Wrocław

agnieszka.franczyk-cegla@ossolineum.pl

\title{
Problemy metodologiczne w identyfikacji anonimów typograficznych na podstawie druków krakowskich $\mathrm{z}$ lat 1601-1620
}

\begin{abstract}
Methodological Problems in the Identification of Anonymous Imprints on the Basis of Cracow Printed Materials from the Years 1601-1620
\end{abstract}

The beginning of the $17^{\text {th }}$ century in Cracow was a period when a number of books appeared on the market in which the title page only contained information about the place of publication, but not the name of the printer. These so-called anonymous imprints included mainly popular and occasional literature. The main reason for not publishing the name of printers was the fear of censorship, which was locally the responsibility of the University of Cracow and the Catholic Church. Nowadays, the identification of typographic anonyms, which until now has been the subject of causal studies usually conducted as bywork during other research projects, allows us to get to know the history of particular printing houses and the literary culture of a given area. The aim of this paper is to look at the issue of anonymous imprints from the methodological point of view, i.e. to present the most effective methods of discovering the printing houses that published the books and pamphlets in question. The emphasis is placed on describing the advantages and disadvantages of typographic and typographic-archival methods in the context of the changing realities in Cracow's foundries and printing houses at the turn of the $16^{\text {th }}$ and $17^{\text {th }}$ centuries. Methodological problems will be discussed on the basis of a corpus of examples collected 
by the author, including anonymous publications from Cracow printing houses in the years 1601-1620 (about 800 titles) by Jan Szarfenberger, Szymon Kempini, and Wojciech Kobyliński, among others.

Keywords: Cracow printing, anonymous imprints, chapbooks, occasional literature

\section{Koniec XVI i początek XVII wieku to okres dużych zmian w historii krakowskiego drukarstwa. Powoli znikają duże, wielopokoleniowe oficyny wydawnicze, które dominowały przez ostatnich kilkadziesiąt lat ${ }^{1}$, wzrasta liczba mniejszych, często efemerycznych i źle wyposażo- nych warsztatów drukarskich produkujących tanią i łatwą do zbycia literaturę dewocyjną, moralizatorską i okolicznościową, pojawiają się nielegalne przedruki ${ }^{2}$, a rynek książki zalewają publikacje tłoczone w Krakowie przez anonimowych drukarzy, czyli tak zwane anonimy typograficzne publikowane w języku polskim i łacińskim³. Ich liczba}

${ }^{1}$ Na przykład w oficynie Macieja Wirzbięty po śmierci drukarza w 1605 roku ukazały się jeszcze tylko trzy druki w latach 1605, 1606 i 1609. Przez kolejne trzy lata trwał proces między spadkobiercami zakończony zamknięciem drukarni oraz sprzedażą wyposażenia warsztatu i zasobu typograficznego. Podobnie w przypadku Drukarni Łazarzowej, która po wycofaniu się Jana Januszowskiego w 1601 roku z działalności drukarskiej przeszła w dzierżawę Bazylego Skalskiego, a w 1615 roku została sprzedana przez synów Januszowskiego Maciejowi Jędrzejowczykowi i jego żonie Zofii. Zniknęły także drukarnie Mikołaja Szarfenbergera i Mikołaja Loba, których zasoby typograficzne po śmierci drukarzy trafiły dłuższą lub krótszą drogą do warsztatu Franciszka Cezarego. Zob. S. Jasińska, Co się stało z drukarniq Wirzbięty?, „Rocznik Biblioteki Narodowej” 4 (1968), s. 147-153; J. Ptaśnik, Cracovia impressorum, Lwów 1922, s. 49, 61-61; J. Pirożyński, Kraków, w: Drukarze dawnej Polski od XV do XVIII wieku, t. 1: Małopolska, cz. 2: Wiek XVII-XVIII, vol. 1: A-K, red. J. Pirożyński, Kraków 2000, s. 345.

${ }^{2}$ Zob. na przykład: J. Pirożyński, Nielegalne XVII-wieczne edycje „Psałterza Dawidowego" Jana Kochanowskiego i „Eneidy” w przekładzie Andrzeja Kochanowskiego (tzw. poddruki), „Biuletyn Biblioteki Jagiellońskiej” 16 (1964), s. 5-20; J. Wójtowicz, Szymon Kempini drukarz krakowski z pierwszej połowy XVII wieku, „Rocznik Biblioteki Polskiej Akademii Nauk w Krakowie" 41 (1996), s. 29-30.

${ }^{3}$ Anonimy typograficzne były przedmiotem przyczynkowych badań, nie poświęcano im jednak szerszych osobnych publikacji. Zob. na przykład: K. Badecki, Literatura mieszczańska w Polsce XVII wieku, Lwów 1925. 
w pierwszym dwudziestoleciu XVII wieku sięgnęła około 800 tytułów ${ }^{4}$, powiększając się znacznie w porównaniu z okresami wcześniejszymi. Tematycznie obejmują one literaturę popularną (sowizdrzalską, satyry antyreformacyjne, kalendarze, nowiny) oraz literaturę okolicznościową. Szczególny rozkwit odnotowała wówczas literatura sowizdrzalska - w latach 1611-1620 ukazało się 60 tytułów, w tym ponad 40 pierwodruków, liczne anonimowo. Pod względem edytorskim stały one, podobnie zresztą jak cała ówczesna produkcja typograficzna, na niższym poziomie niż druki tłoczone $\mathrm{w}$ okresie renesansu.

Wśród powodów, dla których drukarze nie umieszczali swego nazwiska na wyrobach $\mathrm{z}$ własnych warsztatów, prym wiodła obawa przed cenzurą. W Krakowie o rolę cenzora spierał się wówczas uniwersytet z Kościołem katolickim. Formalnie cenzorem był biskup, który cedował uprawnienia na rektora Akademii. Do roku 1617 konflikty cenzorskie rozwiązywane były przez rektora i dotyczyły głównie paszkwili i kalendarzy drukowanych bez korekty i zezwolenia ówczesnego astrologa uniwersyteckiego Jana Brożka. Kiedy w 1617 roku nowym biskupem krakowskim mianowano Marcina Szyszkowskiego, przejął on zwyczajową rolę rektorów, ustalając nawet wysoką karą pieniężną i ekskomunikę dla rektorów, cenzorujących i aprobujących książki bez upoważnienia biskupa ${ }^{5}$. Wyjątkowo gorliwie Szyszkowski przystąpił w swej funkcji cenzora do walki z literaturą niemoralną, przede wszystkim sowizdrzalską. Rozpoczęły się wówczas przed kurią biskupią procesy drukarzy i księgarzy dotyczące tłoczenia literatury

4 Liczba opracowana na podstawie danych zebranych z Bibliografii polskiej Karola Estreichera, t. 8-36, Kraków 1891-2014. Może ona być większa, ponieważ bibliografia mogła niektórych tytułów lub edycji nie odnotować. Rocznie wydawano wówczas po kilkanaście anonimów typograficznych, na przykład w 1601 roku - 10, w 1605 - 14, w 1610 - 13, w 1616 - 19, w 1620 - 20. Wyjątkowe były lata 1608 i 1615, kiedy wydano odpowiednio 38 i 30 tytułów bez wyrażenia drukarza. Prawdopodobnie wpływ na to miały wydarzenia polityczne i związana z tym wzmożona autocenzura prewencyjna, lecz kwestia ta wymaga głębszych badań. Zob. też M. Malicki, Druki krakowskie z pierwszej połowy XVII wieku w statystyce, „Rocznik Biblioteki Narodowej” 37-38 (2006), s. 123-124.

5 P. Buchwald-Pelcowa, Cenzura $w$ dawnej Polsce. Między prasą drukarska a stosem, Warszawa 1997, s. 114. 
sowizdrzalskiej, a w wydanej staraniem Szyszkowskiego w 1617 roku kolejnej edycji Indeksu ksiąg zakazanych wykaz autorów i tytułów polskich obejmujących tego typu literaturę jest znacznie dłuższy niż w dwóch poprzednich Indeksach ${ }^{6}$. Akcja kurii biskupiej przyniosła skutki - już w latach 1621-1630 liczba drukowanych tytułów literatury sowizdrzalskiej zmniejszyła się o połowę, do 31, w tym 14 pierwodruków, a w latach kolejnych, 1631-1640, do 24, w tym około 12 to pierwodruki'.

W przypadku literatury popularnej drukarze często nie podawali na karcie swojego nazwiska, słusznie obawiając się reakcji władz na tłoczenie książek zawierających nieakceptowalne treści religijne, polityczne lub obyczajowe ${ }^{8}$. Dużo bardziej zróżnicowane były powody nieumieszczania nazwiska drukarza na drukach okolicznościowych. W anonimowych warsztatach wychodziły spod pras druki weselne i pogrzebowe, druki związane z Akademią Krakowską (dysertacje doktorskie, utwory poetyckie z różnych okazji dedykowane mecenasom profesorów i studentów), druki tyczące się króla i jego otoczenia. Tematycznie nie znajdowały się one w kręgu zainteresowań organów kontrolnych i nie istnieje wspólny czynnik decydujący o niewytłoczeniu na stronie tytułowej nazwiska drukarza. Pewną regularność wykazują jedynie druki okolicznościowe weselne. W tych napisanych w języku polskim w latach 1601-1620 na pięciu spośród wszystkich piętnastu wydanych w tym okresie podano nazwisko drukarza: w epitalamium z 1601 roku na wesele bliżej nieznanego Stanisława Dębińskiego, w dwóch wierszowanych utworach na wesele Dymitra i Maryny Mniszkówny oraz w dwóch utworach na wesele prominentnej

${ }^{6}$ Index librorum prohibitorum, Kraków: Andrzej Piotrkowczyk, 1617, k. I5v.-I7.

7 P. Buchwald-Pelcowa, Cenzura..., s. 111-147; J. Pirożyński, Kraków, s. 348; K. Budzyk, H. Budzykowa, J. Lewański, Literatura mieszczańska w Polsce, t. 1, Warszawa 1954, s. 51.

${ }^{8}$ Wzmożona cenzura, począwszy od końca XVI wieku, to trend ogólnoeuropejski. Jak piszą Lucien Febvre i Henri-Jean Martin: „Księgarze i drukarze, którzy nie byliby, co najmniej raz w ciągu życia, ścigani - stają się rzadkością” (Narodziny książki, przeł. A. Kocot, M. Wodzyńska-Walicka, Warszawa 2014, s. 243). 
szlachty ${ }^{9}$. Aż cztery tyczą się zatem znanych i ważnych dla ówczesnej Polski osobistości. Z pozostałych dziesięciu druków dziewięć to anonimy typograficzne dotyczące zaślubin przedstawicieli średniej szlachty lub mieszczan. Kraków nie posiadał przepisów zabraniających druku i rozdawania gościom wesel i pogrzebów wierszy ułożonych na te okoliczności w przypadku, gdy nowożeńcy lub zmarli byli niższego stanu - tak jak na przykład w Toruniu, gdzie w 1623 roku zabroniono tego typu praktyk na weselach lub pogrzebach rzemieślników - lecz krakowscy drukarze zdecydowanie chętniej sygnowali swą produkcję druków okolicznościowych weselnych, gdy dotyczyły one znanych osób mogących przynieść korzyść typografom ${ }^{10}$. W tych przypadkach mogli nawet finansować wydanie druków. Publikacje okolicznościowe skierowane do mniej dostojnych nowożeńców, finansowane zapewne przez autora lub rodzinę, często nie miały natomiast nazwiska drukarza na karcie tytułowej, być może nawet na żądanie zamawiających. Wśród innych powodów niesygnowania przez drukarzy własnych wyrobów znalazły się problemy prawne z dziedziczeniem drukarni, nielegalne przedruki dzieł bez praw autorskich, a nawet nielegalne wykorzystanie materiału typograficznego, pochodzącego na przykład z kradzieży w oficynie innego impresora ${ }^{11}$.

Identyfikacja anonimów typograficznych zawsze stanowiła element badań księgoznawczych, służąc konkretnym celom: poznawaniu produkcji danych drukarni, dalszych losów oficyn oraz związków między drukarzami, a także kultury literackiej danego obszaru. Podstawową metodą stosowaną w tego typu analizach była

9 Zob. K. Mroczek, Epitalamium staropolskie między tradycją literacką a obrzędem weselnym, Wrocław 1989, s. 148-151.

10 Wyjątkiem były tłoczone anonimowo druki dotyczące zaślubin Zygmunta III.

11 Na przykład Franciszek Cezary w 1635 roku zarzucał Bartłomiejowi Kwaśniowskiemu przed sądem, że ten nieuczciwie przekonał jego dwóch czeladników, by wynieśli dla niego z drukarni Cezarego materiały drukarskie (linie metalowe i czcionki majuskulne), które Cezary rozpoznał w gotowym druku Kwaśniowskiego. Zob. R. Żurkowa, Spory drukarzy krakowskich, „Rocznik Biblioteki Polskiej Akademii Nauk w Krakowie” 39 (1994), s. 20. 
metoda typograficzna wypracowana w XIX wieku przy badaniach nad inkunabułami, w których przypadku metoda archiwalna, czyli kwerendy w archiwach w poszukiwaniu wzmianek o drukarzach, często była niewystarczająca z powodu niezachowania się źródeł lub ich niezwykle skąpego charakteru, jeżeli chodzi o samą produkcję drukarską. Rozpoznawanie drukarni na podstawie czcionki danej oficyny sprawdziło się w inkunabułach, gdzie stopień indywidualizacji kroju pisma był bardzo wysoki, lecz stopniowe uniezależnienie się rytowników i giserów od drukarń sprawiło, że już w połowie XVI wieku, także w Polsce, stosowane kroje pism stawały się coraz bardziej ujednolicone. Standaryzacja ta wynikała ze względów praktycznych: pojawiło się coraz więcej odlewni produkujących elementy zasobu typograficznego, a właścicielom drukarni bardziej opłacało się kupować gotowe garnitury czcionek niż wykonywać je we własnym warsztacie. W mniejszym stopniu ujednolicenie dotyczyło w XVI wieku innych elementów zasobu, takich jak na przykład ozdobniki drukarskie czy inicjały, które stały się podstawowym czynnikiem typograficznym służącym badaczom do identyfikacji ówczesnych anonimów ${ }^{12}$. W praktyce zastosowanie metody typograficznej w identyfikacji anonimów drukarskich polega na zestawieniu dostępnego zasobu $\mathrm{z}$ danej oficyny i porównaniu go $\mathrm{z}$ anonimami, a gdy znajdzie się dopasowanie, na obserwacji zastosowania i przeobrażeń w czasie poszczególnych elementów zasobu, z najczęściej stosowaną obserwacją „stopnia zużycia materiału typograficznego", to jest głównie drzeworytów. Należy tu podkreślić jednak, że klocki drzeworytowe są wbrew pozorom bardzo trwałe i - o ile nie zjedzą ich korniki lub nie ulegną zniszczeniu (np. połamaniu) - mogą być używane przez lata; precyzyjniej jest zatem mówić o konkretnych czynnikach zużycia, na przykład uszkodzeniach, niż

${ }^{12}$ Więcej na temat początków tej metody i jej zastosowania w inkunabulistyce zob. H. Bułhak, Metoda typograficzna $w$ badaniach nad dawna książka. Uwagi i refleksje, „Biuletyn Poligraficzny” 10 (1977), nr 2, s. 37-52; B. Bieńkowska, Metody bibliologiczne $w$ badaniach dziejów nauki, „Kwartalnik Historii Nauki i Techniki” 34 (1989), nr 2, s. 331-342. 
jedynie o zużyciu, które może implikować przykładowo ścieranie się, co w przypadku materiału drzeworytowego jest praktycznie niezauważalne na odbitkach, zwłaszcza przy niedbałym nałożeniu farby czy na papierze gorszej jakości, cienkim, niezaklejonym ani przed, ani po druku, z rozmazaną farbą drukarską.

$\mathrm{W}$ przypadku druków szesnastowiecznych metoda typograficzna obejmuje wnioskowanie nie tylko na podstawie zasobu, lecz także cech składu, i wspomagana jest metodą archiwalną, proweniencyjną, a także filologiczną, czyli badaniem języka i ortografii. Już przy anonimach szesnastowiecznych badacze przestrzegali bowiem, by w metodzie typograficznej stosować „zdwojoną ostrożność” i wspierać ją innymi metodami ${ }^{13}$. Anonimy typograficzne z XVII wieku stawiaja przed badaczami jeszcze większe wyzwania i trudności ${ }^{14}$, a identyfikacja drukarza wydaje się niekiedy prawie niemożliwa. Co jest tego powodem? Zarówno w przypadku druków w języku polskim, gdzie używano szwabachy, jak i druków w języku łacińskim, gdzie posługiwano się antykwą, czcionka wykazywała duży stopień ujednolicenia. Stosowane w drukach polskich pismo gotyckie było znormalizowane i pojawiało się przeważnie w trzech wielkościach: 109-110 mm i 88-89 mm (tekstowe, licząc wysokość 20 wierszy) oraz 75-76 mm (komentarzowe). Już pod koniec XVI stulecia działały w Krakowie odlewnie zaopatrujące niektóre oficyny w identyczne czcionki. Na przełomie XVI i XVII wieku niemal identyczna szwabacha, a także fraktura, pojawia się u Szarfenbergerów, Siebeneichera, Piotrkowczyka i innych pomniejszych drukarzy. Prawie nierozróżnialnym materiałem drukarskim dysponowali na przykład Andrzej Piotrkowczyk i Wojciech Kobyliński do 1600 roku, co skłoniło badaczy do przypuszczeń, że Kobyliński zaopatrzył się w czcionki u Piotrkowczyka, korzystając z jego aparatów odlewniczych ${ }^{15}$. Tak silne ujednolicenie

${ }^{13}$ H. Bułhak, Metoda typograficzna..., s. 47.

${ }^{14}$ Zob. na przykład: J. Wójtowicz, Szymon Kempini..., s. 33.

${ }_{15}$ Po roku 1600 Kobyliński wymienił czcionki. Zob. M. Zychowiczowa, Kobyliński Wojciech, w: Drukarze dawnej Polski od XV do XVIII wieku, t. 1: Małopolska, cz. 1: Wiek XV-XVI, red. A. Kawecka-Gryczowa, Wrocław 1983, s. 104. 
szwabachy jest konsekwencją w prowadzenia dużo czytelniejszego jej kroju w drugiej połowie wieku XVI, który to odlał dla Jana Januszowskiego działający w drugiej połowie XVI wieku (ok. 1568-1593?) giser Konrad Forster. Pismo to upowszechniło się w innych typografiach: krakowskich, poznańskich u Jana Wolraba i Jana Rossowskiego, rakowskich u Sebastiana Sternackiego i Aleksego Rodeckiego, a później pojawiło się między innymi w Warszawie, Gdańsku, Zamościu i w innych drukarniach Korony. Różnice w kroju czcionek czasami dotyczą jedynie kształtu poszczególnych liter, które odbiegają od powszechnego kroju, i wynikają z niedostatecznych umiejętności giserów i rytowników. Siedemnastowieczna szwabacha była pod względem kroju repliką szwabachy szesnastowiecznej.

Antykwą, która zdominowała zasoby typograficzne polskich drukarń aż do schyłku lat 70. XVII wieku, była renesansowa antykwa typu aldyńskiego w jej francuskiej plantinowskiej odmianie. Podobnie jak w przypadku szwabachy, w antykwę lub matryce sporządzone w działających w Krakowie giserniach zaopatrywały się tłocznie w innych miastach, a pewne widoczne różnice są konsekwencją indywidualnych odchyleń przy produkcji, a nie zamiarem wprowadzenia innego typu pisma ${ }^{16}$.

Dużą wartość identyfikacyjną posiada zastosowany w drukach materiał o charakterze dekoracyjnym. I choć krakowskie anonimy typograficzne z początku XVII wieku to druki niewielkie objętościowo, zazwyczaj kilkukartkowe w formacie quarto i przeważnie pozbawione rozbudowanego materiału dekoracyjnego w rodzaju ozdobnych ram czy dobrej jakości drzeworytów, to zastosowane zdobienia pozwalają na identyfikację drukarń w większym stopniu niż krój pisma. Sprowadzone są one do prostych ramek, pojedynczych drobnych ozdobników, dekoracyjnych inicjałów i winiet, nie odbiegając stylistyką od ówczesnych trendów europejskich. Materiał zdobniczy w większości

${ }^{16}$ M. Juda, Pismo drukowane w Polsce XV-XVIII wieku, Lublin 2001, s. 113, 188; A. Kawecka-Gryczowa, M. Zychowiczowa, Gdzie i kiedy drukowano „Historyje o chwalebnym zmartwychwstaniu Pańskim”?, „Biuletyn Biblioteki Jagiellońskiej” 31 (1981), s. 114. 
druków ma funkcję identyfikującą. Nawet tak niewielki ozdobnik jak rozpowszechniony przez drukarnię Łazarzową czterolistny kwiatek, występujący w wielu różnych odmianach i pojawiający się przez ponad pół wieku u różnych drukarzy, może po głębokiej analizie posłużyć jako wskaźnik pomocniczy przy identyfikacji. Nie należy jedynie stosować materiału ilustracyjnego jako wyłącznego elementu identyfikującego, ponieważ zdarzało się, że materiał ten krążył między warsztatami w drodze sprzedaży. Tak było między innymi z oficyną Macieja Wirzbięty, w której około roku 1587 nastąpił kryzys w produkcji. Drukarz najprawdopodobniej zaczął zatem wyzbywać się części materiału drzeworytowego - Piotrkowczyk nabył 67 klocków drzeworytowych z Postylli Reja do swojej Postylli mniejszej Wujka z 1590 roku, a Kobyliński na przykład winietę ramkową oraz drzeworyt do Lecha wzbudzonego, który u Wirzbięty w dziele Aleksandra Gwagnina Sarmatiae Europeae descriptio z 1578 roku wyobrażał Łokietka ${ }^{17}$.

Osobną kwestię stanowią inicjały drzeworytowe, których krój i stylistyka pełnią nierzadko funkcję wyróżniającą zasób danej oficyny. W praktyce na przełomie XVI i XVII wieku można zaobserwować przypadki, gdy różni drukarze używali tych samych inicjałów w tym samym okresie. Tak było na przykład w przypadku inicjału "J" użytego w 1595 roku w anonimowej oficynie ${ }^{18}$, w 1599 i 1609 roku przez Wojciecha Kobylińskiego ${ }^{19}$, w 1601 i 1603 roku przez Jakuba Siebeneichera ${ }^{20}$, w 1605 roku przez anonima ${ }^{21}$, a w 1611 roku przez Jana Szarfenbergera ${ }^{22}$ (il. 1). Najczęściej tego typu występowania danego elementu zdobniczego z jednej tłoczni

17 A. Kawecka-Gryczowa, M. Zychowiczowa, Gdzie i kiedy drukowano..., s. 117-118, przyp. 13-14.

18 Proces Konfoederaciey, Kraków [s.n.] 1595.

19 [1:] K. Warszewicki, O śmierci Anny Rakuszanki, Kraków: Wojciech Kobyliński, 1599. [2:] J.A. Kmita, Phoenix, Kraków: Wojciech Kobyliński, 1609.

20 [1:] P. Simplician, Manelle duchowne, Kraków: Jakub Siebeneicher, 1601. [2:] S. Grochowski, August wzbudzony, Kraków: Jakub Siebeneicher, 1603.

${ }^{21}$ J. Daniecki, Panny z Helikonu, Kraków [s.n.] 1605.

22 F. Arias, Zdrój wody żywej, Kraków: Jan Szarfenberger, 1611. 
u innego drukarza tłumaczy się relacją dziedzic - spadkobierca czy sprzedający - kupujący ${ }^{23}$. Bardzo często tłumaczy się tego typu zależność wśród drukarzy działających w tym samym czasie także tym, że mogli oni wymieniać się poszczególnymi elementami ze swych zasobów lub pożyczać je sobie, zwłaszcza elementy zdobnicze. Choć niewykluczone, że przypadki takie mogły się zdarzać, nie należy traktować tego jako szerszego zjawiska czy zasady ${ }^{24}$. Wręcz przeciwnie - materiały źródłowe udowadniają, że drukarze bardzo niechętnie rozstawali się ze swoim materiałem. Krzysztof Plantin tylko raz pożyczył garnitur czcionek ze swej oficyny innemu drukarzowi, Janowi Masiusowi, a i to pod presją wysoko postawionych osób $^{25}$. Podobnie Szymon Szymonowic opisywał w liście do Jana Zamojskiego stosunki wśród drukarzy niemieckich, relacjonując, że trudno tam dostać jakieś dobre matryce, bo „każdy się doma z swym kryje", a te byle jakie są wyjątkowo drogie ${ }^{26}$.

W przytoczonym przykładzie inicjału „” zależności te nie mogły wystąpić pomiędzy Kobylińskim a Siebeneicherem z punktu widzenia chronologicznego. Niemożliwe jest także, że wymieniali się oni owym klockiem, bowiem inicjały nie są identyczne i różnią się między sobą jednym szczegółem: u Kobylińskiego w prawym dolnym rogu występuje regularnie drobne uszkodzenie uwidaczniające się na odbiciu przerwaną linią. Inicjał Kobylińskiego i Siebeneichera

${ }^{23}$ W przypadku materiału ilustracyjnego dochodzi jeszcze możliwość wypożyczenia.

${ }^{24}$ Już dziewiętnastowieczni badacze przestrzegali przed takim uproszczeniem. Zob. na przykład A.W. Pollard, The Transference of Woodcuts in the XV and XVI Centuries, w: idem, Old Picture Books with Other Essays on Bookish Subjects, London 1902, s. 73-98. Autor, choć zajmuje się wcześniejszym okresem, słusznie zauważa, że „we have also to be very careful in our examination of cuts before building any theories of borrowing”, po czym opierając się na ilustracjach z dwóch wydań inkunabułów, pozornie identycznych, stwierdza: „we are really confronted with copies so closely imitated that it requires a minute comparaison to show that they are printed from different blocks" (ibidem, s. 74).

25 L. Voet, The Golden Compasses, vol. 2, Amsterdam 1972, s.125.

26 J. Ptaśnik, Cracovia impressorum, s. 384, nr 778. 


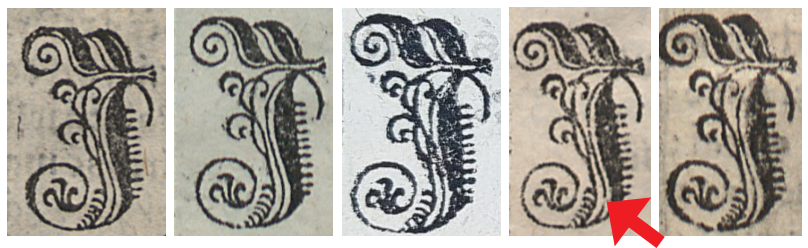

Il. 1. Inicjał „”” wykorzystywany przez różnych drukarzy krakowskich. Od lewej: Anonim identyfikowany jako A. Piotrkowczyk (1595; Ossol. XVI. Qu.2264); Jakub Siebeneicher (1601; Ossol. XVII-583); Anonim (1605; Ossol. XVII-579); Wojciech Kobyliński (1609; Ossol. XVII-24); Jan Szarfenberger (1611; Ossol. XVII-2015). Strzałką zaznaczono uszkodzenie materiału powtarzające się w innych drukach W. Kobylińskiego

pochodzą zatem z dwóch różnych klocków, choć identyczna jest wielkość i odległość między poszczególnymi elementami inicjału. Jak to możliwe? Warto rozważyć inną hipotezę, uwzględniającą praktyczną stronę produkcji klocków i punkt widzenia rzemieślników handlujących swymi wyrobami. Otóż jedną z pierwszych czynności przy wytwarzaniu klocka drzeworytowego jest naniesienie rysunku na jego powierzchnię. Stosowane dawniej metody przenoszenia wzorów to:

1) rysowanie bezpośrednio na klocku (najczęstsza technika),

2) przyklejanie karty z rysunkiem na klocek i wyrzynanie wzoru przez papier (częściej stosowana na Wschodzie, ale używana też w XVI wieku we Francji),

3) przenoszenie wzoru $z$ karty papieru na klocek.

Jedną z najprostszych technik stosowanych w przypadku trzeciej metody, czyli transferu z karty na klocek, jest pokrycie tylnej części karty z rysunkiem czerwoną lub czarną kredą, położenie karty tą stroną na klocku i odrysowanie wówczas linii rysunku twardym narzędziem (używano pióra jaskółczego), tak że rysunek odbijał się kredą na klocku²7.

27 A.M. Hind, Introduction to a History of Woodcut, vol. 1, New York 1963, s. 17; A.W. Pollard, The Transference of Woodcuts..., s. 81. 
Pozwalało to na pewną mechanizację pracy drzeworytników. Innymi słowy - formsznajder na podstawie jednego wzoru mógł kopiować swoją pracę, czyli wyrzynać identyczne klocki, które później sprzedawał różnym oficynom, co czyniło produkcję mniej kosztowną, a sam materiał bardziej powszechnym. Fakt, że klocki były kopiowane, udowodniły ostatnio nawet badania nad komputerowymi technikami rozpoznawania obrazów prowadzone na podstawie drzeworytów z szesnasto- i siedemnastowiecznych druków popularnych ballad angielskich. Używając komputerowej metody geometrycznej, badacze wykazali, że możliwe jest stwierdzenie, czy identyczne na pierwszy rzut oka ilustracje drzeworytowe pochodzą z tego samego czy innego (kopiowanego) klocka drzeworytowego ${ }^{28}$. Różnice w odbiciach identycznych obrazów z dwóch odrębnych klocków są właściwie niezauważalne, lecz istnieją, tak jak w inicjale „”" u Kobylińskiego i Siebeneichera, ponieważ wytwory nawet wyjątkowo sprawnych rąk nigdy nie są identyczne co do milimetra i stopnia odchylenia, zwłaszcza przy ryciu w drewnie. Hipoteza, że formsznajderzy posługiwali się tym samym wzorem, a jego przeniesienie na klocek wykonywali prostą techniką transferu opisaną wyżej, ma też swoje uzasadnienie finansowe. Był to bowiem tani i szybki sposób na zwiększenie produkcji; wyrób klocka na podstawie zupełnie nowego, indywidualnego wzoru dostarczonego z oficyny kosztowałaby bowiem więcej i wymagałaby dłuższego oczekiwania na materiał. Identyczność materiału wynikałaby zatem $\mathrm{z}$ uniwersalnych reguł rządzących popytem i podażą na rynku produkcyjnym, przede wszystkim z mody oraz pogarszającej się sytuacji ekonomicznej, wymuszającej poszukiwanie tanich metod wytworu książek. W przypadku literatury popularnej, sprzedawanej na kramach w tysiącach egzemplarzy, ważną rolę odgrywała także u drukarzy chęć szybkiego wprowadzenia wydania i jego wielokrotnych przedruków na rynek.

28 J.S. Chung et al., Re-presentations of Art Collections, w: Computer Vision ECCV 2014 Workshops. Zurich, Switzerland, September 6-7 and 12, 2014, Proceedings, part 1, Cham 2015, s. 85-100. 
Inaczej rzecz się ma $z$ winietami drzeworytowymi stosowanymi przez różnych drukarzy, które jak pokazała dotychczasowa kwerenda, wykazują duże podobieństwo, ale nie identyczność. Przykładem jest winieta $\mathrm{z}$ barokowym maszkaronem $\mathrm{z}$ otwartymi ustami. Winiety użyte zostały jako finaliki w drukach krakowskich z 1605 roku u Mikołaja Szarfenbergera (winieta A) i Wojciecha Kobylińskiego (winieta B $)^{29}$. Różnice pomiędzy nimi są niezwykle drobne i obejmują brak ozdoby w winiecie B na środkowej wstędze oraz sposób przedstawienia języka u węża nad głową maszkaronów: rozdwojony na winiecie A i cały na winiecie B (il. 2). Obie winiety nie były nowe, ponieważ wykazują pewne ślady zniszczeń w postaci ukruszonych fragmentów wstęg (na ilustracji zaznaczone grubszymi strzałkami); ta od Kobylińskiego była w takim stanie już kilka lat wcześniej, gdy w 1599 roku drukarz użył jej na stronie tytułowej druku O śmierci Anny Rakuszanki ${ }^{30}$. Winieta A z drukarni Szarfenbergera została użyta ponownie w anonimie typograficznym z 1607 roku zatytułowanym Iudicium albo zdanie i wyrok z nauki astrologskiej Bernata z Krakowa. Mikołaj Szarfenberger już wówczas nie żył - zmarł w roku poprzednim w wieku 91 lat, będąc „zdziecinniałym starcem”31. Dziedzice podzielili między siebie kamienicę z drukarnią przy ul. Grodzkiej. Był wśród nich Jan Szarfenberger, z zawodu będący drukarzem, który współpracował z ojcem od co najmniej 1570 roku. Powszechnie uważa się, że warsztat miał dwuletnią przerwę, spowodowaną

${ }^{29}$ Podobny typ drzeworytowej winiety $\mathrm{z}$ maszkaronem pojawia się także w zasobie typograficznym drukarza, który w 1600 roku tłoczył Carmen polskolatinum cechu pijackiego. Według Alodii Kaweckiej-Gryczowej ten zabytek literatury sowizdrzalskiej wyszedł spod prasy Aleksego Rodeckiego. Na przełomie XVI i XVII wieku w Krakowie co najmniej trzech drukarzy posługiwało się podobną w stylu winietą. Zob. A. Kawecka-Gryczowa, Ariańskie oficyny wydawnicze Rodeckiego i Sternackiego. Dzieje i bibliografia, Wrocław 1974, s. 157.

${ }_{30}$ Pojawia się także między innymi w 1606 roku na stronie tytułowej Poema de acerbissimo Christi Domini cruciatu oraz jako finalik w druku Votum szlachcica polskiego.

31 S. Tomkowicz, Przyczynki do historyi kultury Krakowa w pierwszej połowie XVII wieku, Lwów 1912, s. 306. 
procesem spadkowym pomiędzy licznym rodzeństwem i perturbacjami finansowymi, a Jan uruchomił drukarnię w 1609 roku, kiedy to wydał Kolędę Moskiewską, zaciągając na rozruch przedsiębiorstwa dużą pożyczkę ${ }^{32}$. W rzeczywistości jednak druki z oficyny Szarfenbergerów ukazywały się w latach 1607-1608, choć bez podania nazwiska drukarza. Było to zapewne spowodowane wspomnianymi sprawami spadkowymi - dopiero po ich zakończeniu, w 1609 roku, Jan mógł oficjalnie sygnować druki swym nazwiskiem jako dziedzic drukarni. Wcześniej wydał między innymi w 1607 roku Iudicium Bernata z Krakowa, na co wskazuje materiał typograficzny (czcionka, inicja$ł y^{33}$, winiety) pochodzący z Szarfenbergerowskiej tłoczni, używany także przez Jana w latach późniejszych, gdy już podpisywał swe druki. Opisywana wyżej winieta A z druku Mikołaja Szarfenbergera z 1605 roku została użyta w Iudicium Bernata z Krakowa, lecz była już w dużo gorszym stanie - fragment lewej wstęgi, w 1605 roku nadkruszony, uległ złamaniu, przez co ozdobnik ten jest dość charakterystyczny. Jan Szarfenberger użył go również na przykład w 1611 roku w druku łacińskim Marcina Wojnara Carmen nuptiale novis coniugibus d. Ioanni Kilarovicio et d. Annae Praisneroviciae. Ta sama winieta i inicjał $\mathrm{z}$ tego samego garnituru czcionek pojawia się $\mathrm{w}$ anonimie typograficznym Discurs na konfederacyja z 1615 roku Piotra Skargi. Produkcja typograficzna Jana Szarfenbergera znana jest do 1614 roku, a sam drukarz popadał co raz w kłopoty finansowe, które doprowadziły do tego, że w 1616 roku drukarnię określano jako „zrujnowaną”. Posłużenie się jedynie metodą typograficzną pozwoliłoby jednak przypisać mu wydrukowanie tego drobnego druczku nawet przy ówczesnych kłopotach z oficyną. Nowe światło kładzie jednak na sprawę kwerenda archiwalna, gdyż w księgach krakowskich z 1625 roku, już po śmierci Jana Szarfenbergera, czytamy, że jego szwagier, Mateusz Gruszczyński,

32 A. Mańkowska, Z. Wawrykiewicz, Szarfenberger Jan, w: Drukarze dawnej Polski..., t. 1, cz. 2, vol. 1, s. 611.

${ }^{33}$ Por. na przykład inicjał „W” w Marsie moskiewskim Jana Żabczyca z 1606 roku. 

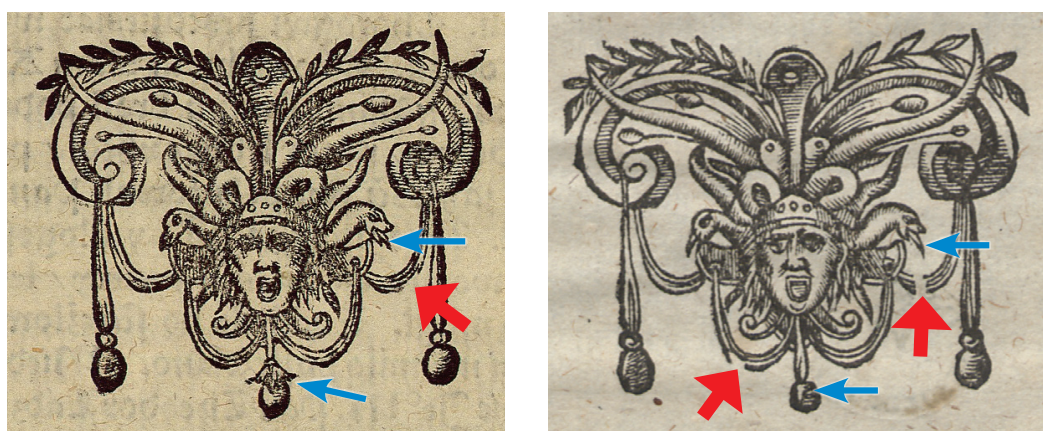

Il. 2. Winiety z zasobu typograficznego Mikołaja Szarfenbergera i Wojciecha Kobylińskiego użyte w drukach z 1605 roku (egz. od lewej: BN XVII.3.5244; Ossol. XVII-575). Małymi strzałkami zaznaczono różnice, dużymi uszkodzenia

żądał od Franciszka Cezarego zastawionych przez Jana u Żydów prasy drukarskiej i materiału typograficznego, które Cezary, na prośbę Szarfenbergera, wykupił „około 10 lat” wcześniej:

Temu jest około 10 lat mając nieb. Jan Szarfenberger drukarz krak. prasę drukarską i materyej 6 centnarów na litery, którą caygiem zowią, w zastawie u żydów i obawiając się, aby mu tam długością czasu nie zginęła, uprosił pozwanego [tj. Franciszka Cezarego - A.F.-C.], aby to wszystko (prasę i cayg) wykupił i do siebie wziął [...]. Pozwany dał za to sumę 120 polskich $[\ldots]^{34}$.

Discurs na konfederacyja mógł zostać zatem wydrukowany albo jeszcze przez Szarfenbergera, albo już przez Cezarego - na pewno został wytłoczony Szarfenbergerowską czcionką, jednak z powodu niedokładności wyrażenia „około 10 lat” nie sposób z pewnością rozstrzygnąć przez którego drukarza ${ }^{35}$. Pierwszy druk sygnowany „W Drukárni Fránćißká Cezárego” wyszedł po 12 maja 1616 roku.

34 S. Tomkowicz, Przyczynki..., s. 278.

35 Ibidem, s. 308, 277-278. 
Było to Kazanie na pogrzebie Mikołaja Radziwiłła autorstwa Marcina Widziewicza, tłoczone już czcionkami z zasobu Jana Szarfenbergera (szwabacha tekstowa większa $=110 \mathrm{~mm}$, omawiany wyżej Szarfenbergerowski inicjał „”). Od tego druku oficjalnie datuje się obecnie początek działania oficyny Cezarego ${ }^{36}$, choć w starszych opracowaniach przesuwa się początek działalności drukarza na rok 1612. Słusznie postulował zatem Marian Malicki, że „należy przyjrzeć się więc anonimom drukarskim z lat 1612-1616 i, wykorzystując zebraną dokumentację typograficzną, podjąć próbę określenia adresu wydawniczego przynajmniej części z nich" ${ }^{37}$. Analogicznie rzecz ma się z Janem Szarfenbergerem - z pewnością drukował w latach 1606-1614 więcej, niż mu się przypisuje. Druków sygnowanych przez niego z imienia i nazwiska jest dość mało, toteż tym cenniejsza jest zatem analiza typograficzna anonimów drukarskich pozwalająca poszerzyć listę tytułów, które wychodziły z jego warsztatu.

Metoda typograficzna, wsparta źródłami archiwalnymi, jest najbardziej efektywna przy identyfikacji anonimów typograficznych, nawet jeśli - jak w opisywanym wyżej przypadku - dostarcza więcej pytań niż odpowiedzi. Wielokrotnie jednak połączenie tych dwóch metod rozwiewa wątpliwości i przypuszczenia badacza. Dobrym przykładem jest wykorzystanie drzeworytu z popiersiem mężczyzny w płaszczu i kapeluszu, którego rodowód sięga wieku XVI. Pojawił się on między innymi w anonimie typograficznym z 1615 roku Wódka albo gorzałka, a w 1618 roku użył go Bazyli Skalski do drukowania Lekarstw domowych, druku będącego skróconą wersją Zielnika Syreniusza, który Skalski wcześniej drukował (il. 3). Czy można uznać Skalskiego za drukarza Wódki albo gorzałki na podstawie porównania tylko do jednego druku? Wątpliwości rozwiewają wiadomości dostarczane ze źródeł archiwalnych. Otóż w 1632 roku spod pras

${ }^{36}$ K. Korotajowa, Cezary Franciszek, w: Drukarze dawnej Polski..., t. 1, cz. 2, vol. 1, s. 82 .

${ }_{37}$ M. Malicki, Repertuar wydawniczy drukarni Franciszka Cezarego starszego 1616-1651, Kraków 2000, s. 12. 
anonimowego drukarza wyszedł inny druk sowizdrzalski Rybałt stary wędrowny. Na wokandzie sądu krakowskiego jego sprawa pojawiła się w 1643 roku. Drukarze Marcin Filipowski, Bartłomiej Kwaśniowski i Walerian Piątkowski tłumaczyli się z wydawania druków sowizdrzalskich pod takimi tytułami jak Nawara, Vetus ars, Rybałt, Walna wyprawa i Padawany. Filipowski i Kwaśniowski zeznali wówczas, że przed dziesięciu laty odbili w swej drukarni wymienione pozycje z wyjątkiem Padawanów:

Instigator proposuit, quod ipsi libellos certos in depravationem iuventutis exprimere et divulgere audent. In praesentia famatorum Martini Philipowski, Bartholomaei Kwaśniowski, Valeriani Piątkowski, civium et typographum Cracoviensium citatorum ex adverso praesentium, libellos huiusmodi nominari et declarari sibi petentibus. Ex adverso offici libellos nomero 5 videlicet Nawara, Vetus ars, Rybalt, Walna wyprawa et Padawany dictos facto produxit propositionique suae directae per citatos responderi postulavit. In directa responsione predicti famati Philipowski et Kwaśniowski principales citati agnoverunt se in officina sua typographica praefatos excepto Padawany ante annos decem impressisse, sed ad praesens eosdem non divulgasse neque divulgare ${ }^{38}$.

[Oskarżyciel oświadczył, że ci ośmielili się wytłoczyć i rozpowszechniać pewne książki ku deprawacji młodzieży. W obecności sławetnych Marcina Filipowskiego, Bartłomieja Kwaśniowskiego, Waleriana Piątkowskiego, obywateli i drukarzy krakowskich, pozwanych z przeciwnej strony obecnych, na ich żądanie, by tego rodzaju książki wymienić, ze strony sądu oskarżyciel przedstawił książki w liczbie 5, zatytułowane Nawara, Vetus ars, Rybałt, Walna wyprawa i Padawany i zażądał, by oskarżeni odpowiedzieli na jego zarzuty przedstawione przed sądem. W bezpośredniej odpowiedzi wspomniani wyżej sławetni Filipowski i Kwaśniowski, główni oskarżeni, przyznali, że przed dziesięciu laty wydrukowali w swej oficynie typograficznej wymienione książki oprócz Padawanów, lecz w chwili obecnej ani ich nie rozpowszechniali, ani nie rozpowszechniają]. (przeł. A. F.-C.)

${ }_{38}$ Archiwum Kurii Metropolitalnej w Krakowie, Acta officialia, t. 130, s. 293294, cyt. za: J. Kracik, Nieznani impresorowie, autor i bibliopole druków sowizdrzalskich w Krakowie, „Biuletyn Biblioteki Jagiellońskiej” 32 (1983), s. 65-66. 

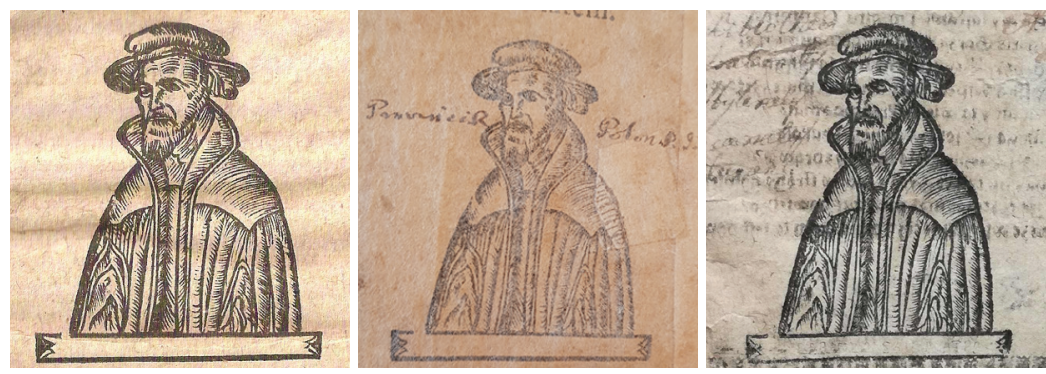

Il. 3. Drzeworyt z drukarni Bazylego Skalskiego i jego spadkobiercy Marcina Filipowskiego. Od lewej: Anonim 1615 (Lwowska Narodowa Naukowa Biblioteka Ukrainy im. W. Stefanyka, CT-II 79808); Bazyli Skalski 1618 (Ossol. XVII-6428); Marcin Filipowski, Bartłomiej Kwaśniowski 1532 (BJ 311008)

Wymieniany Rybałt to właśnie ów druk z 1632 roku. Źródła archiwalne potwierdzają zatem, że drukarzami byli Filipowski i Kwaśniowski. Filipowski był ożeniony z Anną Skalszczanką, córką Bazylego Skalskiego - wiadomo, że mieszkali razem z teściem już w 1613 roku ${ }^{39}$. Filipowski musiał zatem przejąć warsztat teścia, w którego zasobie znajdował się ów drzeworyt. Dzięki metodzie typograficzno-archiwalnej odkryto więc nie tylko nazwisko drukarzy Rybatta z 1632 roku, lecz także uzyskano potwierdzenie, że anonimowe druki sowizdrzalskie z początku XVII wieku były drukowane przez Skalskiego, oraz wcześniej niedostępne informacje dotyczące losów drukarni Skalskiego - do tej pory uważano bowiem, że losy tej drukarni pozostają nieznane ${ }^{40}$.

Podsumowując, najważniejsze trudności napotykane podczas identyfikacji anonimów typograficznych to podobieństwo i identyczność materiału typograficznego, którym posługiwali się różni drukarze.

39 R. Żurkowa, Filipowski-Staniec Marcin, w: Drukarze dawnej Polski..., t. 1, cz. 2, vol. 1, s. 171.

${ }^{40}$ R. Żurkowa, Skalski Bazyli, w: Drukarze dawnej Polski od XV do XVIII wieku, t. 1: Małopolska, cz. 2: Wiek XVII-XVIII, vol. 2: L-Z i druki żydowskie, red. J. Pirożyński, Kraków 2000, s. 578. 
Dokładna analiza poszczególnych elementów zasobów typograficznych z jednoczesnym wykorzystaniem różnych metod pozwala jednak - przynajmniej w niektórych przypadkach - odkryć, kto tłoczył dany druk. Identyfikacja drukarzy, co należy także podkreślić, nie jest jedynie sztuką per se, lecz służy konkretnym celom, takim jak poznawanie produkcji typograficznej poszczególnych drukarni, dalszych losów dużych, mieszczańskich oficyn krakowskich oraz związków między drukarzami, a w rezultacie poszerza nasze informacje na temat kultury książki i rzemiosła w danym okresie.

\section{Bibliografia}

\section{Źródła}

Arias F., Zdrój wody żywej, Kraków: Jan Szarfenberger, 1611.

Bernat z Krakowa, Iudicium abo zdanie i wyrok z nauki astrologskiej, Kraków [s.n.] 1607.

Daniecki J., Panny z Helikonu, Kraków [s.n.] 1605.

Grochowski S., August wzbudzony, Kraków: Jakub Siebeneicher, 1603.

Index librorum prohibitorum, Kraków: Andrzej Piotrkowczyk, 1617.

Jodko Lithuanus, Carmen polskolatinum cechu pijackiego, Kraków [s.n.] 1600.

Kmita J.A., Phoenix, Kraków: Wojciech Kobyliński, 1609.

Poema de acerbissimo Christi Domini cruciatu, Kraków [s.n.] 1606.

Potański J., Wódka albo gorzałka, [s.l., s.n.] 1614.

Rybałt stary wędrowny, [s.l., s.n.] 1632.

Simplician P., Manelle duchowne, Kraków: Jakub Siebeneicher, 1601.

Skalski B., Lekarstwa domowe, Kraków: B. Skalski, 1618 [wyd. 2].

Skarga P., Discurs na konfederacyją, Kraków [s.n.] 1615.

Skarga P., Proces konfederacyjej, Kraków [s.n.] 1595.

Votum szlachcica polskiego ojczyznę wiernie mitującego, Kraków [s.n.] 1606.

Warszewicki K., O śmierci Anny Rakuszanki, Kraków: Wojciech Kobyliński, 1599.

Widziewicz M., Kazanie na pogrzebie Mikołaja Radziwiłła, Kraków: Franciszek

Cezary [po 12.05.1616].

Wojnar M., Carmen nuptiale novis coniugibus d. Ioanni Kilarovicio et d. Annae Praisneroviciae, Kraków: Jan Szarfenberger, 1611. 


\section{Opracowania}

Badecki K., Literatura mieszczańska w Polsce XVII wieku, Lwów 1925.

Bieńkowska B., Metody bibliologiczne w badaniach dziejów nauki, „Kwartalnik Historii Nauki i Techniki” 34 (1989), nr 2, s. 331-342.

Buchwald-Pelcowa P., Cenzura $w$ dawnej Polsce. Między prasą drukarską a stosem, Warszawa 1997.

Budzyk K., Budzykowa H., Lewański J., Literatura mieszczańska w Polsce, t. 1, Warszawa 1954.

Bułhak H., Metoda typograficzna w badaniach nad dawną książka. Uwagi i refleksje, „Biuletyn Poligraficzny” 10 (1977), nr 2, s. 37-52.

Chung J.S. et al., Re-presentations of Art Collections, w: Computer Vision - ECCV 2014 Workshops. Zurich, Switzerland, September 6-7 and 12, 2014, Proceedings, part. 1, Cham 2015, s. 85-100.

Febvre L., Martin H.-J., Narodziny książki, przeł. A. Kocot, M. Wodzyńska-Walicka, Warszawa 2014.

Hind A.M., Introduction to a History of Woodcut, vol. 1-2, New York 1963.

Jasińska S., Co się stało z drukarniq Wirzbięty?, „Rocznik Biblioteki Narodowej” 4 (1968), s. 147-153.

Juda M., Pismo drukowane w Polsce XV-XVIII wieku, Lublin 2001.

Kawecka-Gryczowa A., Ariańskie oficyny wydawnicze Rodeckiego i Sternackiego. Dzieje i bibliografia, Wrocław 1974, s. 157.

Kawecka-Gryczowa A., Zychowiczowa M., Gdzie i kiedy drukowano „Historyje o chwalebnym zmartwychwstaniu Pańskim”?, „Biuletyn Biblioteki Jagiellońskiej" 31 (1981), s. 113-118.

Korotajowa K., Cezary Franciszek, w: Drukarze dawnej Polski od XV do XVIII wieku, t. 1: Małopolska, cz. 2: Wiek XVII-XVIII, vol. 1: A-K, red. J. Pirożyński, Kraków 2000, s. 82-100.

Kracik J., Nieznani impresorowie, autor i bibliopole druków sowizdrzalskich w Krakowie, „Biuletyn Biblioteki Jagiellońskiej” 32 (1983), s. 53-66.

Malicki M., Druki krakowskie z pierwszej połowy XVII wieku w statystyce, „Rocznik Biblioteki Narodowej" 37-38 (2006).

Malicki M., Repertuar wydawniczy drukarni Franciszka Cezarego starszego 16161651, Kraków 2000.

Mańkowska A., Wawrykiewicz Z., Szarfenberger Jan, w: Drukarze dawnej Polski od XV do XVIII wieku, t. 1: Małopolska, cz. 2: Wiek XVII-XVIII, vol. 1: A-K, red. J. Pirożyński, Kraków 2000, s. 609-614.

Mroczek K., Epitalamium staropolskie między tradycja literacka a obrzędem weselnym, Wrocław 1989.

Pirożyński J., Kraków, w: Drukarze dawnej Polski od XV do XVIII wieku, t. 1: Małopolska, cz. 2: Wiek XVII-XVIII, vol. 1: A-K, red. J. Pirożyński, Kraków 2000, s. $344-352$. 
Pirożyński J., Nielegalne XVII-wieczne edycje „Psałterza Dawidowego” Jana Kochanowskiego i „Eneidy” w przekładzie Andrzeja Kochanowskiego (tzw. poddruki), „Biuletyn Biblioteki Jagiellońskiej” 16 (1964), s. 5-20.

Pollard A.W., The Transference of Woodcuts in the XV and XVI Centuries, w: idem, Old Picture Books with Other Essays on Bookish Subjects, London 1902, s. 73-98.

Ptaśnik J., Cracovia impressorum, Lwów 1922.

Tomkowicz S., Przyczynki do historyi kultury Krakowa w pierwszej połowie XVII wieku, Lwów 1912.

Voet L., The Golden Compasses, vol. 2, Amsterdam 1972.

Wójtowicz J., Szymon Kempini drukarz krakowski z pierwszej połowy XVII wieku, „Rocznik Biblioteki Polskiej Akademii Nauk w Krakowie” 41 (1996), s. 29-30.

Zychowiczowa M., Kobyliński Wojciech, w: Drukarze dawnej Polski od XV do XVIII wieku, t. 1: Małopolska, cz. 1: Wiek XV-XVI, red. A. Kawecka-Gryczowa, Wrocław 1983, s. 101-105.

Żurkowa R., Filipowski-Staniec Marcin, w: Drukarze dawnej Polski od XV do XVIII wieku, t. 1: Małopolska, cz. 2: Wiek XVII-XVIII, vol. 1: A-K, red. J. Pirożyński, Kraków 2000, s. 170-192.

Żurkowa R., Spory drukarzy krakowskich, „Rocznik Biblioteki Polskiej Akademii Nauk w Krakowie” 39 (1994), s. 15-23.

Żurkowa R., Skalski Bazyli, w: Drukarze dawnej Polski od XV do XVIII wieku, t. 1: Małopolska, cz. 2: Wiek XVII-XVIII, vol. 2: L-Z i druki żydowskie, red. J. Pirożyński, Kraków 2000, s. 575-591. 